\title{
Firm Size, Profitability, Leverage as Determinants of Audit Report Lag: Evidence From Indonesia
}

\author{
Lailah Fujianti $^{1} \&$ Indra Satria ${ }^{1}$ \\ ${ }^{1}$ Faculty of Business \& Economics, Pancasila University, Jakarta, Indonesia \\ Correspondence: Lailah Fujianti, Faculty of Business \& Economics, Pancasila University, Jakarta, Indonesia.
}

Received: June 14, 2019

Accepted: December 20, 2019

Online Published: March 16, 2020

doi:10.5430/ijfr.v11n2p61

URL: https://doi.org/10.5430/ijfr.v11n2p61

\begin{abstract}
This study examines the factors that influence Audit Report Lag in Indonesia. This factor is seen from the financial performance of the company size, profitability and corporate leverage. The research sample was 91 manufacturing companies listed on the Indonesia Stock Exchange (IDX) for the period of 2015 and 2016. The total observation for 2 years amounted to 182. The method of data analysis is random effect models. The results showed that company size and profitability are variables that can shorten Audit Report Lag. Meanwhile, leverage has not empirically proven to have a significant effect. The findings implies that large companies have better information and technology systems compared to smaller companies so as to strengthen internal control and speed of presentation of financial statements. High profitability encourages companies to present financial reports on time so that the impact of ARL decline.
\end{abstract}

Keywords: firm size, profitability, leverage, audit report lag, Indonesia

\section{Introduction}

Timeliness of the presentation of financial statements in accordance with the deadline set by regulations, is an important element for the functioning of the capital market mechanism. The mechanism is intended to provide protection to investors and potential investors. This reason is one of the causes of the timeliness of the presentation of financial statements received attention from various parties including regulators (Krishnan and Yang 2009; Abbott et al. 2012; Bronson et al. 2011). This attention is particularly aimed at the deadline for presenting financial statements. Securities and Exchange Commission (SEC) regulators in several countries including Indonesia have established regulations regarding the deadline to reduce delays in presenting financial statements by many public companies (Lambert et al. 2013).

Financial statements that are presented to the public are generally financial statements that have been audited by an external auditor. This objective is to gain legitimacy and increase public confidence in the accuracy and validity of the financial statements. The audit process takes time so that it will have an impact on the timeliness of the presentation of financial statements. The period of time from the end of the accounting year to the date of issuance of audited financial statements is called Audit Report Lag / ARL (Reheul et al. 2013).

Previous research examines many company size variables in relation to ARL (Suyanto, 2016), profitability (Pham, 2014) and leverage (Ayemere, 2015). Large companies have large resources so they are able to put pressure to present financial reports on time so that they will shorten ARL. However, the results of previous studies indicate the inconsistency of the results of the study. Al-Ghanem and Hegazy (2011) in Kuwait showed that company size had a significant negative effect on ARL, while Iyoha (2012) in Negeria showed no significant effect.

Profitability shows the company's ability to make a profit. This ability shows good company performance. Profitability is one of the many variables associated with ARL, because high profitability is a good new for investors and potential investors. This encourages companies to present financial statements on time (Al-Akra, et al., 2010). However, the results of previous studies show varied results. Voku and Cular's (2014) research results in Crotia show profitability has a significant effect on ARL and vice versa is shown (Oladipupo, 2011) in Nigeria.

Leverage is the ratio of total debt to equity. High leverage can bring risk to the company. This situation requires companies to be more careful in presenting financial statements. In addition, companies with high levels of leverage will come strong pressure from debtors because they want the audited financial statements to be presented more 
quickly, so the ARL predictions will be shortened. The results of studies that examine the relationship of leverage with ARL show variable results. Ahmed and Hossain (2010) conducted a study in Malaysia showing that leverage had a significant effect on ARL, while Fagbemi and Uadiale (2011) in Negeria showed that ARL had no significant effect. Fujianti (2016) showed that previous research on the effect of company size, profitability and leverage on ARL shows varying results in various countries. Therefore, this study will review these variables in the context of the Indonesian state.

\section{Literature Review and Hypothesis Development}

\subsection{Agency Theory}

The relationship between shareholders as principal and managers as agents is explained in the agency theory. Jensen and Meckling (1976) further explained agency theory is a contract between the principal and the agent where the agent is given the authority to act or make decisions on behalf of the principal. Wu et al. 2014 explained that this relationship enabled agents to make strategic decisions regarding the company's operations. Principal as the giver of authority demands accountability reports from agents. One form of agency responsibility is the presentation of financial statements. The financial statements provide information to the principal regarding the financial position, results of operations, changes in capital and cash flow of the company during a certain period. ARL will certainly cause problems in the relationship between principal and agent.

\subsection{Audit Report Lag}

Audit report lag is the closing period of the end of the financial year until the financial statements are published to interested parties (Pizzini et al. 2015). ARL will reduce the usefulness of financial statement information because decision making requires timely information support. (Leventis et al., 2005) explained further that timely financial statements are an important element in assessing the quality of financial information in a country Apadore and Noor, 2015 explained that delays in the presentation of financial statements would reduce the usefulness and economic value of information. Accounting applicable in several countries establishes one of the qualitative characteristics of financial statement information that is presented on time (Eghlaiow, 2012).

ARL can reduce the quality of financial statement information because it is one of the causes of delay in the presentation of financial statements. Anticipating that timely financial report presentation by companies listed on the IDX, the capital market watchdog, now known as the Financial Services Authority (OJK), sets rules and witnesses for delays in presenting financial statements.

\subsection{Effect of Company Size and ARL}

The size of the company which is proxied by log total assets is most associated with ARL. Several previous studies found firm size to be negatively related to ARL. Habiba and Bhuiyan, (2011) explain the negative relationship between company size and ARL because large companies are able to put more pressure on auditors for timely reporting and, in addition, large companies have strong internal controls that can be relied on by auditors, thereby reducing the amount of audit work at the end of the year. Simnett, et al (1995) stated that management of large companies has greater incentives to reduce ARL because it is closely monitored by investors, trade unions, and regulators. Therefore, large companies will have shorter audit time than smaller companies. Ayemere and Elijah (2015) showed a significant negative effect between company size and ARL. For this reason the research hypotheses are as follows:

\section{H1: Firm size has a negative effect on audit report lag}

\subsection{Effect of Profitability on ARL}

Profitability shows the company's ability to make a profit. High profit shows good company performance as well as being a good new company for investors or other interested parties of the company. This encourages companies to present financial statements on time ( $\mathrm{Ng}$ and Tai, 1994). In addition, a low level of profitability will trigger a setback in the publication of financial statements (Carslaw and Kaplan (1991) because low profitability is a bad new company for investors. Companies in this condition will be more careful in presenting financial statement information. facing public reaction to the delivery of the information, the company in this condition also started the audit later than usual so that it would extend the ARL (Ashton, et al 1987) Bae and Woo (2016) showed that profitability had a negative effect on ARL. The alternatives are arranged as follows:

H2: Profitability has a negative effect on ARL 


\subsection{Effect of Leverage on ARL}

Leverage is the ratio between the amount of debt and equity. Leverage reflects the company's ability to pay all of its obligations, both in the form of short-term and long-term debt. Companies with high levels of leverage will have greater financial risk than companies with low levels of leverage (Alali and Elder, 2014). A high degree of leverage brings strong pressure from the debtor to immediately submit financial statements on time (Abdulla, 1996) as a result the company will present financial statements on time. On the other hand, it is possible that companies with higher leverage ratios will disguise the level of risk, thereby delaying publishing their company's annual report by or extending the period of audit work (Modugu et al 2012). Previous research shows a varied relationship between leverage and ARL. Thus the research hypotheses are as follows:

\section{H3: Leverage affects the Audit Report Lag}

\section{Research Methods}

The research sample was 91 manufacturing companies listed on the Indonesia Stock Exchange (IDX) for the period of 2015 and 2016. The total observation for 2 years amounted to 182. The research sample was determined based on purposive sampling with the criteria of (a) presenting 2015 and 2016 financial statements (b) presents financial statements in rupiah.

Data analysis in this study used panel data regression with the Random Effect Model. This method is used after going through the model selection process with the chow test, the Hausman test and the Lagrange Multiplier test. The panel data regression model is as follows:

$$
\mathrm{ARL}=\mathrm{a}+\mathrm{b}_{1} \text { SIZE }+\mathrm{b}_{2} \text { PROFIT }+\mathrm{b}_{3} \text { LEV }+\mathrm{e}
$$

Indicators for each variable are as follows:

$\begin{array}{ll}\text { ARL (Audit Report Lag) }= & \begin{array}{l}\text { The period of time the book closes until the presentation of financial } \\ \text { statements on the IDX }\end{array} \\ \text { Size (Company Size) } & \begin{array}{l}\text { Log total Assets } \\ \text { Return On Assets }\end{array} \\ \text { PROFIT (Profi } & \text { Debt to Equity Ratio }\end{array}$

\section{Research Results and Discussion}

\subsection{Descriptive Statistical Analysis}

Table 1 shows the results of descriptive statistics from a number of observations 182 data. ARL has a maximum value of 98 days, a minimum of 43 days and a mean of 73 days. The size of the company is represented by SIZE with a maximum value of 33.2, a minimum of 25.25 and a mean value of 28.55253 . Profitability is symbolized by ROA with a maximum value of 0.43 , a minimum value of -0.18 and a mean of 0.0365 . Leverage is represented by LEV with a maximum value of 4.75 , minimum 0.00 , and a mean of 0.36 .

Table 1. Descriptive statistics analysis results

\begin{tabular}{lllll}
\hline & ARL & SIZE & PROFIT & LEV \\
\hline Mean & 73.31 & 28.55 & 0.036 & 0.362 \\
\hline Median & 75.00 & 28.37 & 0.020 & 0.300 \\
\hline Maximum & 98.00 & 33.20 & 0.430 & 4.750 \\
\hline Minimum & 43.00 & 25.25 & -0.180 & 0.000 \\
\hline Std.Dev. & 11.50 & 1.661 & 0.082 & 0.545 \\
\hline Skewness & -0.265 & 0.369 & 1.169 & 6.192 \\
\hline Kurtosis & 2.392 & 2.618 & 7.731 & 47.26 \\
\hline Jarque-Bera & 4.930 & 5.240 & 211.21 & 16019.6 \\
\hline Probability & 0.084 & 0.072 & 0.000 & 0.000 \\
\hline Sum & 13344.00 & 5196.56 & 6.650 & 65.89 \\
\hline SumSq.Dev. & 23975.52 & 499.7176 & 1.2371 & 53.82195 \\
\hline Observations & 182 & 182 & 182 & 182 \\
\hline
\end{tabular}




\subsection{Model Selection Criteria}

The model test results can be seen in Table 2 of the Regression Result Panel. The results showed that there are three tests to choose the panel or estimation technique. First, test the chow to choose between the Common Effect method or the Fixed Effect method. Second, the Hausman test to choose between the Fixed Effect method or the Randon Effect method. Third, the Lagrange Multiplier (LM) Test is used to choose between the Pooled OLS method or the Random Effect method. According to the Chow model test the right model is fixed effects because the P-value (Cross-section F) -Chow test shows a significance level of $0.000<0.0500$. According to the Hauman test the right model is random effects because the P (Cross-section Random) Hauman Test shows a significant level of 0.591> 0.050. Furthermore, according to the lagrange multiplier test, the right model is a random effect because the $\mathrm{P}$ (cross-section Random) value of the lagrange multiplier is $0.000<0.050$. Model selection shows that the three models above are random effects models that are appropriate because they meet the requirements in hausman and lagrange multiplier.

Table 2. Regression result panel

\begin{tabular}{|c|c|c|c|c|}
\hline Variable & $\begin{array}{l}\text { Model } \\
\text { test }\end{array}$ & $\begin{array}{l}\text { Fixed } \\
\text { Effects }\end{array}$ & $\begin{array}{l}\text { Random } \\
\text { Effects }\end{array}$ & $\begin{array}{l}\text { Pooled } \\
\text { OLS }\end{array}$ \\
\hline \multirow[t]{2}{*}{$\bar{C}$} & & $153.935^{* * * *}$ & $133.175^{* * * *}$ & $126.981 * * *$ \\
\hline & & (0.000) & $(0.000)$ & $\begin{array}{l}(0.000) \\
\end{array}$ \\
\hline \multirow[t]{2}{*}{ Size } & $(-)$ & $-2.700 * * *$ & $-2.0005^{* * *}$ & $-1.781 * * *$ \\
\hline & & (0.001) & $(0.000)$ & $(0.000)$ \\
\hline \multirow[t]{2}{*}{ Profit } & $(-)$ & $-59.848 * * *$ & $-65.950 * * *$ & $-70.725 * * *$ \\
\hline & & $(0.000)$ & $(0.000)$ & $(0.000)$ \\
\hline \multirow[t]{2}{*}{ Lev } & $(-/+)$ & -3.624 & 0.544 & -0.589 \\
\hline & & $(0.645)$ & $(0.721)$ & $(0.638)$ \\
\hline $\mathrm{R} 2$ & & 0.856 & 0.3877 & 0.382 \\
\hline Adj. R2 & & 5.633 & 37.580 & 38.366 \\
\hline F-stat & & 0.000 & 0.000 & 0.000 \\
\hline DW & & 3.956 & 1.990 & 0.959 \\
\hline $\begin{array}{ll}\mathrm{P}(\text { cross-section } & \text { F)-Chow } \\
\text { test } & \end{array}$ & 0.000 & & & \\
\hline $\begin{array}{l}\mathrm{P}(\text { cross-section } \\
\text { F)-Haumann test }\end{array}$ & 0.591 & & & \\
\hline $\begin{array}{l}\mathrm{P}(\text { cross-section } \\
\text { F)-Langrange Multiplier }\end{array}$ & 0.000 & & & \\
\hline
\end{tabular}

\subsection{Discussion}

The beta coefficient value of company size is -2.005 with a significance level of -value of $0.000<0.050$. This means H1 is accepted so that there is a negative influence of company size on ARL in manufacturing companies listed on the Indonesia Stock Exchange. The results of this study are in line with the results of the study of Ilaboya and Christian (2014), Mukhtaruddin et al (2015), Arifuddin et al (2017). Large companies are able to put pressure on auditors to present audit financial statements faster, thus shortening ARL. Companies with large total assets have shorter ARL compared to companies with low total assets. Assets owned by a company have an influence on the time span of submission of financial statements for several reasons. First, large companies have information systems and technology that are better than small companies so as to strengthen internal control of the company and reduce errors in preparing financial statements so as to facilitate auditors in auditing the financial statements (Carslaw and Kaplan, 
1991). Second, the company has assets to pay high audit fees so that the audit financial statements are presented immediately (Modugu et al., 2012; Susilo, 2018). Third, scale-up large companies are closely monitored by those who need financial statement information so that they face higher pressure to immediately present their financial statements.

Beta profitability coefficient value of $-65,950$ with a significance level of -value of $0.000<0.050$. This means $\mathrm{H} 2$ is accepted. This showed that profitability has a negative effect on ARL in manufacturing companies listed on the Indonesia Stock Exchange. The results of this study are in line with the results of research by Hapsari et al (2016), Karami and Mohammadvand (2016), Rusmin (2017) which states that corporate profitability has a negative effect on ARL. Companies that experience profits will conduct an audit process faster than companies that experience losses.

The leverage coefficient value is -0.544 with a significance level of -value of $0.721>0.050$. This means that $\mathrm{H} 3$ is rejected. Hence, leverage has no effect on ARL in manufacturing companies listed on the Indonesia Stock Exchange. The results of this study are consistent with the results of Adebayo's research (2016) and the contradiction of the results of the research of Lestari and Nuriyatna (2018). Leverage is the proportion of debt to total equity that does not affect the ARL, this is because the auditor in conducting the analysis procedure looks more at the profitability of the company which is a source of profit for stakeholders, so that the auditor in conducting the audit will focus more on the analytical procedures involved. Ibadin et al (2012) stated that companies that have a lot of debt will present financial statements more quickly to convince the debtor of the company's ability to pay its debts. However, this is not proven in this study because leverage shows no effect on ARL. The results of this study also imply that creditors have not put pressure on companies to present financial statements on time and reduce ARL.

\section{Conclusion}

The findings showed that that company size and profitability are variables that can shorten Audit Report Lag. Meanwhile, leverage has not empirically proven to have a significant effect. This means that the size of the company affects ARL because large companies have better information and technology systems compared to smaller companies so as to strengthen internal control and speed of presentation of financial statements. High profitability provides good news for investors thereby encouraging companies to present financial reports on time so that the impact of ARL decline. High leverage often brings strong pressure from debtors to present financial reports immediately, but research has not been able to provide empirical evidence about this.

The findings revealed that companies that get large profits have no reason to postpone the issuance of financial statements and even tend to accelerate the issuance of financial statements, because companies that earn high profits will provide good news to investors and potential investors so that investors are expected to be interested in buying company shares. This buying behavior impacts an increase in the company's stock price. Conversely, companies that suffer losses will try to slow down the publication of financial statements. The auditor will be careful during the audit process to respond to company losses, whether the loss is caused by financial failure or management fraud. This is one of the reasons for the negative relationship between profitability and ARL. In terms of leverage, companies that have a lot of debt will present financial statements more quickly to convince the debtor of the company's ability to pay its debts. However, this is not proven in this study because leverage shows no effect on ARL. The results of this study also imply that creditors have not put pressure on companies to present financial statements on time and reduce ARL.

\section{References}

Abbott, L. J., Parker, S., \& Peters, G. F. (2012). Internal audit assistance and external audit timeliness. Auditing: A Journal of Practice \& Theory, 31(4), 3-20. https://doi.org/10.2308/ajpt-10296

Abdulla, J. Y. A. (1996). The timeliness of Bahraini annual reports. Advances in International Accounting, 9, 73-88.

Adebayo, P. A., \& Adebiyi, W. K. (2016). Effect of firm characteristics on the timeliness of corporate financial reporting: evidence from Nigerian deposit money banks. International Journal of Economics, Commerce and Management, 4(3), 369-381.

Ahmed, A. A. A., \& Hossain, M. S. (2010). Audit report lag: A study of the Bangladeshi listed companies. ASA University Review, 4(2), 49-56. https://doi.org/10.2139/ssrn.3406733

Al-Akra, M., Eddie, I. A., \& Ali, M. J. (2010). The influence of the introduction of accounting disclosure regulation on mandatory disclosure compliance: Evidence from Jordan. The British Accounting Review, 42(3), 170-186. https://doi.org/10.1016/j.bar.2010.04.001 
Alali, F. A., \& Elder, R. J. (2014). Determinants of audit report lag in the banking industry: updated evidence. International Journal of Accounting, Auditing and Performance Evaluation, 10(4), 364-394. https://doi.org/10.1504/IJAAPE.2014.066391

Al-Ghanem, W., \& Hegazy, M. (2011). An empirical analysis of audit delays and timeliness of corporate financial reporting in Kuwait. Eurasian Business Review, 1(1), 73-90.

Arifuddin, K. H., \& Usman, A. (2017). Company Size, Profitability, and Auditor Opinion Influence to Audit Report Lag on Registered Manufacturing Company in Indonesia Stock Exchange. International Journal of Applied Business and Economic Research, 15(9), 353-367.

Ashton, R. H., Willingham, J. J., \& Elliott, R. K. (1987). An empirical analysis of audit delay. Journal of Accounting Research, 275-292. https://doi.org/10.2307/2491018

Ayemere, I. L., \& Elijah, A. (2015). Corporate attributes and audit delay in emerging markets: empirical evidence from Nigeria. International Journal of Business and Social Research, 5(3), 01-10.

Bae, C. H., \& Woo, Y. S. (2016). The effect of CEO turnover on audit report lag and management discretionary report lag: evidence from Korea. Investment Management and Financial Innovations, 13(1), 61. https://doi.org/10.21511/imfi.13(1).2016.05

Bronson, S. N., Hogan, C. E., Johnson, M. F., \& Ramesh, K. (2011). The unintended consequences of PCAOB auditing Standard Nos. 2 and 3 on the reliability of preliminary earnings releases. Journal of Accounting and Economics, 51(1-2), 95-114. https://doi.org/10.1016/j.jacceco.2010.06.002

Carslaw, C. A., \& Kaplan, S. E. (1991). An examination of audit delay: Further evidence from New Zealand. Accounting and Business Research, 22(85), 21-32. https://doi.org/10.1080/00014788.1991.9729414

Eghlaiow, S., Wickremasinghe, G., \& Sofocleous, S. (2012). A review of the empirical determinants of audit delay. Corporate Ownership and Control, 9(2), 511-514. https://doi.org/10.22495/cocv9i2c5art5

Fagbemi, T. O., \& Uadiale, O. M. (2011). An appraisal of the determinants of timeliness of audit report in Nigeria: Evidence from selected quoted companies. In The New Orleans International Academic Conference New Orleans, Louisiana USA.

Fujianti, L. (2016). Ketaatan Hukum Mampukah Memoderasi Hubungan Good Corporate Governance Terhadap Audit Report Lag. Simposiun Nasional Akuntansi XIX. Lampung.

Habib, A., \& Bhuiyan, M. B. U. (2011). Audit firm industry specialization and the audit report lag. Journal of International Accounting, Auditing and Taxation, 20(1), 32-44. https://doi.org/10.1016/j.intaccaudtax.2010.12.004

Hapsari, A. N., Putri, N. K., \& Arofah, T. (2016). The Influence of Profitability, Solvency, and Auditor's Opinion to Audit Report Lag at Coal Mining Companies. Binus Business Review, 7(2), 197-201. https://doi.org/10.21512/bbr.v7i2.1685

Ibadin, I. M., Izedonmi, F., \& Ibadin, P. O. (2012). The association between selected corporate governance attributes, company attributes and timeliness of financial reporting in Nigeria. Research Journal of Finance and Accounting, 3(9), 137-145.

Ilaboya, O. J., \& Christian, I. (2014). Corporate governance and audit report lag in Nigeria. International Journal of Humanities and Social Science, 4(13), 172-180.

Iyoha, F. O. (2012). Company attributes and the timeliness of financial reporting in Nigeria. Business Intelligence Journal, 5(1), 41-49.

Jensen, M. C., \& Meckling, W. H. (1976). Theory of the firm: Managerial behavior, agency costs and ownership structure. Journal of Financial Economics, 3(4), 305-360. https://doi.org/10.1016/0304-405X(76)90026-X

Karami, N., \& Mohammadvand, Z. (2016). The relationship among financial and non-financial characteristics and duration of implementation and completion of the audit of listed companies in tehran stock exchange. European Journal of Economic and Financial Research, 1(1), 37-48.

Kogilavani, A. (2012). Determinants of audit report lag and corporate governance in Malaysia. Doctoral dissertation, Universiti Utara Malaysia.

Krishnan, J., \& Yang, J. S. (2009). Recent trends in audit report and earnings announcement lags. Accounting Horizons, 23(3), 265-288. https://doi.org/10.2308/acch.2009.23.3.265 
Lambert, T. A., Jones, K. L., \& Brazel, J. F. (2013). Unintended Consequences of Accelerated Filings: Are Mandatory Reductions in Audit Quality Associated with Reductions in Earnings Quality?. Working Paper, Lehigh University.

Lestari, S. Y., \& Nuryatno, M. (2018). Factors affecting the audit delay and its impact on abnormal return in Indonesia Stock Exchange. International Journal of Economics and Finance, 10(2), 48-56. https://doi.org/10.5539/ijef.v10n2p48

Leventis, S., Weetman, P., \& Caramanis, C. (2005). Determinants of audit report lag: Some evidence from the Athens Stock Exchange. International Journal of Auditing, 9(1), 45-58. https://doi.org/10.1111/j.1099-1123.2005.00101.x

Modugu, K. E. E., \& Ikhatua, G. (2012). Determinants of audit delay: empirical evidence from Nigeria. The International Journal of Business and Finance Research, 8(2), 21-28.

Mukhtaruddin, M., Oktarina, R., Relasari, R., \& Abukosim, A. (2015). Firm and Auditor Characteristics, and Audit Report Lag in Manufacturing Companies Listed on Indonesia Stock Exchange during 2008-2012. Expert Journal of Business and Management, 3(1), 13-26.

Ng, P. P., \& Tai, B. Y. (1994). An empirical examination of the determinants of audit delay in Hong Kong. The British Accounting Review, 26(1), 43-59. https://doi.org/10.1006/bare.1994.1005

Oladipupo, A. O. (2017). Impact of corporate international linkage on the incidence of audit delay in Nigeria. EBSU Journal of Social Sciences and Humanities, 4(1).

Pham, T., Dao, M., \& Brown, V. L. (2014). Investment opportunities and audit report lags: Initial evidence. Accounting and Finance Research, 3(4), 45-57. https://doi.org/10.5430/afr.v3n4p45

Pizzini, M., Lin, S., \& Ziegenfuss, D. E. (2014). The impact of internal audit function quality and contribution on audit delay. Auditing: A Journal of Practice \& Theory, 34(1), 25-58. https://doi.org/10.2308/ajpt-50848

Reheul, A. M., Van Caneghem, T., \& Verbruggen, S. (2013). Audit report lags in the Belgian non-profit sector: an empirical analysis. Accounting and Business Research, 43(2), 138-158. https://doi.org/10.1080/00014788.2013.777828

Rusmin, R., \& Evans, J. (2017). Audit quality and audit report lag: case of Indonesian listed companies. Asian Review of Accounting, 25(2), 191-210. https://doi.org/10.1108/ARA-06-2015-0062

Simnett, R., Aitken, M., Choo, F., \& Firth, M. (1995). The determinants of audit delay. Advances in Accounting, $13(1), 1-20$.

Suryanto, T. (2016). Audit delay and its implication for fraudulent financial reporting: a study of companies listed in the Indonesian stock exchange. European Research Studies, 19(1), 18. https://doi.org/10.35808/ersj/503

Susilo, D. E. (2018). The effects of corporate social responsibility on corporate value. Arthatama Journal of Business Management and Accounting, 2(1), 1420-1426.

Vuko, T., \& Culat, M. (2014). Finding determinants of arl by pooled ols regression analysis. Croatian Operational Research Review, 5, 81-91. https://doi.org/10.17535/crorr.2014.0030

Wu, X., Lan, Y., \& Liu, H. (2014). Optimal revenue-sharing contract based on forecasting effort for uncertain agency problem. International Journal of Machine Learning and Cybernetics, 5(6), 971-979. https://doi.org/10.1007/s13042-014-0243-3 